OPEN ACCESS

Edited by:

Dawei Lv,

Shandong University of Science and Technology, China

Reviewed by:

$\mathrm{Hu} \mathrm{Li}$,

Southwest Petroleum University,

China

Shuai Yin,

Xi'an Shiyou University, China

*Correspondence:

Lianbo Zeng

Ibzeng@sina.com

Specialty section: This article was submitted to Sedimentology, Stratigraphy and Diagenesis,

a section of the journal Frontiers in Earth Science

Received: 09 February 2021 Accepted: 07 April 2021 Published: 12 May 2021

Citation:

Zeng L, Lyu W, Zhang Y, Liu G and Dong $S$ (2021) The Effect of Multi-Scale Faults and Fractures on

Oil Enrichment and Production

in Tight Sandstone Reservoirs: A Case Study in the Southwestern Ordos Basin, China

Front. Earth Sci. 9:664629. doi: 10.3389/feart.2021.664629

\section{The Effect of Multi-Scale Faults and Fractures on Oil Enrichment and Production in Tight Sandstone Reservoirs: A Case Study in the Southwestern Ordos Basin, China}

\author{
Lianbo Zeng ${ }^{1,2 *}$, Wenya Lyu ${ }^{1,2}$, Yunzhao Zhang ${ }^{1,2}$, Guoping Liu ${ }^{1,2}$ and Shaoqun Dong ${ }^{1,2,3}$ \\ ${ }^{1}$ State Key Laboratory of Petroleum Resources and Prospecting, China University of Petroleum, Beijing, China, ${ }^{2}$ College \\ of Geosciences, China University of Petroleum, Beijing, China, ${ }^{3}$ College of Science, China University of Petroleum, Beijing, \\ China
}

The Chang 8 Member of the Upper Triassic Yanchang Formation in the southwestern Ordos Basin is a typical tight sandstone reservoir and has an average porosity of $8.60 \%$ and air permeability $0.20 \mathrm{mD}$. Multi-scale faults and fractures are widely developed in these reservoirs. In this study, three-dimensional seismic data, outcrops, cores, imaging logs, and thin sections were used to classify faults and fractures at multiple scales. Combined with the oil production data, the influence of multi-scale faults and fractures on the oil enrichment and production was analyzed. The results show multi-scale faults and fractures can be divided into six levels: type-I faults, type-II faults, large-scale fractures, mesoscale fractures, small-scale fractures, and micro-scale fractures. As the scale decreases, the number of fractures increases in a power function. Type-I faults cut the caprocks and are not conducive to the preservation of oil. Type-ll faults connect the source rocks and reservoirs and are migration channels of the oil source. Large-scale fractures cut the mudstone interlayer and are the seepage channel inside the reservoir. Mesoscale fractures are controlled by thick interlayers, and small-scale fractures are restricted by thin interlayers or layer interfaces. These fractures are the main seepage channels and effective storage spaces. Micro-scale fractures serve as important storage spaces for these reservoirs. The case study of oil reservoir development proves that type-I faults have the greatest impact on fluid flow, while wells drilled into the typeII faults zone have a higher oil production capacity. The oil production changes with the development degree of fractures in different scales, strikes, and positions of faults. Meso- and small-scale fractures are the key to influencing the early single-well production, and micro-scale fractures are conducive to the stable production of single wells. Consequently, multi-scale faults and fractures have significantly different effects on the oil enrichment and production of tight sandstone reservoirs, and the research conclusions can guide to the exploration and development of such similar reservoirs.

Keywords: multi-scale faults and fractures, oil enrichment and production, tight sandstone reservoir, Yanchang formation, Ordos Basin 


\section{INTRODUCTION}

Tight sandstones of the Upper Triassic Yanchang Formation with a matrix permeability of less than $0.1 \mathrm{mD}$ under subsurface conditions are the primary targets for tight oil exploration and development in the Ordos Basin (Han et al., 2017; Jia, 2017). These tight sandstone reservoirs have low porosity and permeability, strong heterogeneity, and widely developed natural fractures (Ameen et al., 2012; Gong et al., 2019). Natural fractures, which can provide effective storage space and improve the seepage capacity, are an essential factor influencing the oil and gas distribution in tight sandstone reservoirs (Laubach et al., 2010; Zeng et al., 2013; Liu et al., 2020a). Therefore, the study of natural fractures is of great significance to the exploration and development of tight oil and gas.

The development and distribution of natural fractures are controlled by rock mechanical units (Gross et al., 1995; Strijker et al., 2012; Liu et al., 2020b). Differences in the mechanical properties and thickness of the rock mechanical unit determine the extension and termination of fractures, making natural fractures characterized with multi-scale (Cooke et al., 2006; Larsen et al., 2010). The quantitative statistics of fracture parameters, such as the density, aperture, and length, need to be considered under multiple-scale. The aperture and length of multi-scale fractures obey the power-law distribution (Berkowitz, 2002; Olson, 2003; Laubach and Ward, 2006). Fractures with different scales have various contributions to tight sandstone reservoirs. Large-scale fractures with low porosity but high permeability are effective migration channels, while small and micro-scale fractures with low permeability can provide important storage spaces for these reservoirs on account of the high porosity (Zeng et al., 2020). The study of multi-scale fractures is useful to better understand the contribution of natural fractures to the distribution and development of oil and gas in tight sandstone reservoirs.

The genetic types of natural fractures include tectonic, diagenetic, and overpressure-related fractures in tight sandstone in the Upper Triassic Yanchang Formation of the Ordos Basin. Among them, the tectonic fractures developed during the Late Jurassic to Early Cretaceous and Paleogene are the dominant ones (Zeng et al., 2007). The fracture development is controlled by lithology, rock mechanical units, sedimentary microfacies, diagenetic facies, and reservoir heterogeneity (Zeng et al., 2008; Gong et al., 2019). Besides, the contribution of natural fractures to reservoir permeability and their influence on oil and gas development are also discussed (Lyu et al., 2019). However, there is a lack of research and understanding of fracture scales and the differences in the effects of multi-scale fractures on reservoirs.

In this paper, various data including outcrops, 3D seismic data, imaging logs, cores, and thin sections were used to conduct research. Based on the development characteristics, the faults and fractures are divided into different levels, and the influence of multi-scale fault-fractures on the oil and gas accumulation and productivity of tight sandstone reservoirs is also discussed. The research results provide an example for understanding the role of multi-scale fault-fractures in tight oil and gas exploration and development.

\section{GEOLOGICAL SETTING}

\section{Location and Structure}

The Ordos Basin is located in the central of China and has an area of about $37 \times 10^{4} \mathrm{~km}^{2}$ (Figure 1A). It is separated from the Yinshan Mountains by the Hetao Graben in the north, faces the Qinling Mountains by the Weihe Graben in the south, reaches Liupan Mountain in the west, and reaches Lvliang Mountain in the east. This basin can be divided into six first-level structural units (Figure 1B), including the Yimeng Uplift, Weibei Uplift, West Margin Thrust Belt, Yishan Slope, Tianhuan Depression, and Jinxi Flexfold Belt (Han et al., 2014; Wang et al., 2017). The study area is located in the southern of the Tianhuan Depression and is a west-dipping monoclinic structure as a whole. Some small uplifts of low amplitude and NEE-SWW, NWW-SEE, NW-SE, and near E-W strike faults are developed in the study area (Figure 1C).

\section{Stratigraphy}

The Ordos Basin developed Paleozoic marine and MesozoicCenozoic terrestrial strata (Figure 2). The Paleozoic marine strata are generally natural gas reservoirs, while the Mesozoic terrestrial strata are mainly oil reservoirs (Zeng and Li, 2009). The Yanchang Formation of the Upper Triassic is one of the most important oilbearing formations in the Ordos Basin (Duan et al., 2008). The Yanchang Formation consists of Chang 1 to Chang 10 oil layer groups from top to bottom (Tang et al., 2014), with a thickness of about 430-620 m. Among them, the Chang 8 sandstones are the major target for the tight oil (Hao et al., 2017; Wang et al., 2020).

\section{Reservoir}

The Chang 8 member of the southwestern Ordos Basin comprises shallow braided river delta deposits, with dominant sedimentary microfacies of distributary channel, estuary bar, sheet sand, and distributary bay. The reservoir lithology is debris feldspar sandstones with fine, fine-medium, and silty-fine grains. The storage space is mainly intergranular dissolved pores, residual primary pores, and microfractures, in addition to a small amount of intragranular dissolved pores, mold pores, and intercrystalline pores (Liang and Guo, 2017). The reservoir porosity distribution ranges from 4.4 to $12 \%$, with an average of $8.6 \%$, and the air permeability of these reservoirs is between 0.10 and $0.65 \mathrm{mD}$, with an average of $0.20 \mathrm{mD}$, which is a typical tight oil sandstone reservoir (Lyu et al., 2017b).

\section{In situ Stress}

The direction of present in situ stress can be obtained from borehole breakouts and drilling-induced fractures from imaging logs, and the value of present in situ stress comes from rock acoustic emission experiment, hydraulic fracturing, and acoustic logging data (Hillis and Reynolds, 2003; Zoback et al., 2003; Rajabi et al., 2016; Ju et al., 2017). Based on the above methods, the maximum and minimum principal stresses are in the horizontal direction, and the intermediate principal stress is vertical in the southwest of Ordos Basin. The dominant direction of the maximum 


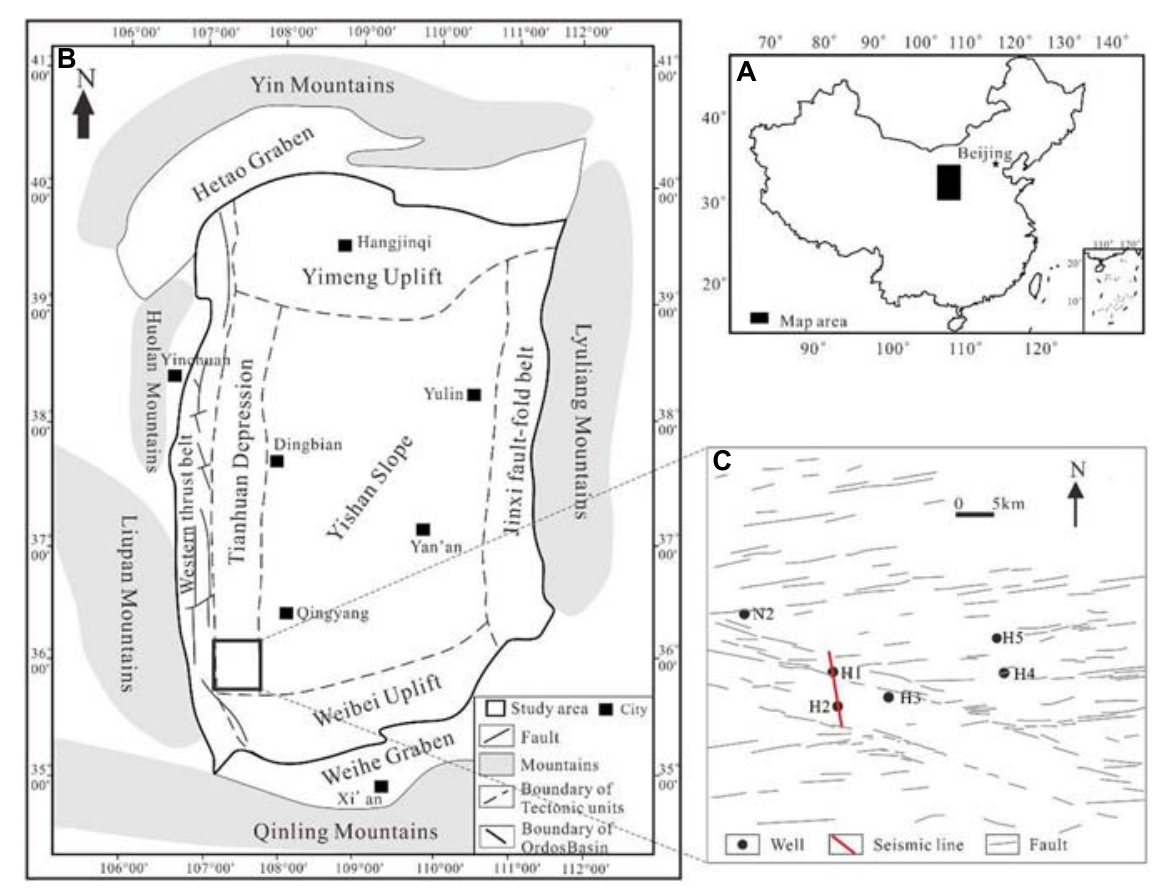

FIGURE 1 | Location map of the Ordos Basin, study area, wells, and fault systems (modified from Zeng and Li, 2009; Lyu et al., 2016; Lyu et al., 2017a, 2019). (A) Location of the Ordos Basin. (B) Location of the study area and tectonic units of the Ordos Basin. (C) Location of wells, seismic line, and fault systems in the study area.

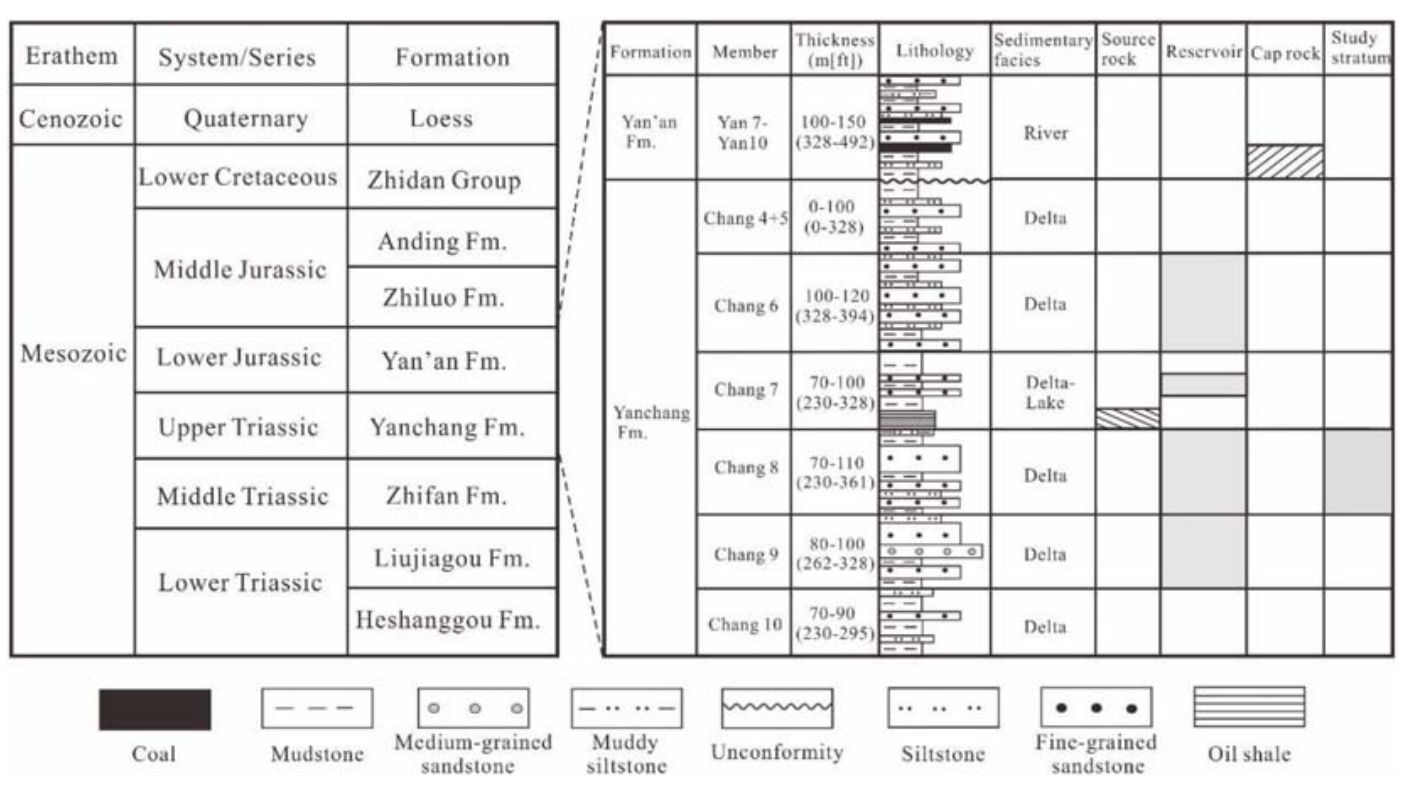

FIGURE 2 | Schematic stratigraphy and hydrocarbon potential of the southwestern Ordos Basin (modified from Lyu et al., 2019). Fm.= Formation.

horizontal compressive stress is $60-70^{\circ}$. The value of present in situ stress has a good linear relationship with buried depth, and the stress gradients of the maximum, intermediate, and minimum principal stresses are 0.0301, 0.0212, and 0.0165 $\mathrm{MPa} \cdot \mathrm{m}^{-1}$, respectively (Zeng and Li, 2009; Lyu et al., 2019).

\section{DATA SET AND METHODOLOGY}

This study uses cores of $2,413.33 \mathrm{~m}$ from 127 wells, microresistivity imaging logs from nine wells, 225 thin sections, and oil test data from more than 200 wells in the tight sandstones of the Upper Triassic Yanchang Formation in the southwestern Ordos 
Basin. Various materials, including 3D seismic data, outcrops, cores, imaging logs, and thin sections, are integrated for multiscale fault-fracture evaluation, reducing the uncertainty caused by a single data.

Fault parameters, including length, fault displacement, and occurrence, are obtained by interpreting 3D seismic data. Large-scale fractures come from the outcrops and post-stack attributes (coherence, curvature, and variance) of 3D seismic data (Chen et al., 2016; Xu et al., 2020). Meso- and small-scale fracture parameters, including strike, dip, density, aperture, and length, are obtained through outcrops, cores, and imaging logs (Hennings et al., 2000; Khoshbakht et al., 2012). The density of meso- and small-scale fractures refers to linear density, which is the number of fractures per unit length in the normal direction of the fracture surface (Shi et al., 2020). Micro-scale fracture parameters such as length, aperture, and density are derived from thin section observation (Ameen and Hailwood, 2008). Microscale fracture density means the areal density, the total length of fractures per unit area (Zeng et al., 2008).

The micro-resistivity imaging logs can provide highresolution two-dimensional images of the surrounding wellbore containing petrophysical information. These images convert the difference in resistivity or acoustic impedance caused by meso- and small-scale fractures into different colors, which can accurately characterize fracture properties such as aperture, length, and occurrence (Ameen and Hailwood, 2008; Barton et al., 2009).

\section{RESULTS}

\section{Fault-Fracture Scale Division}

According to the development characteristics and distribution scale, the faults and fractures in the tight sandstones of the Upper Triassic Yanchang Formation in the Ordos Basin can be divided into six levels: type-I faults, type-II faults, large-scale fractures, mesoscale fractures, small-scale fractures, and microscale fractures (Figure 3 and Table 1). In this article, we mainly discuss the classification of tectonic fractures.

The interpretation of $3 \mathrm{D}$ seismic data shows that these faults are mainly strike-slip faults, with a nearly upright dip angle, a small fault displacement, and an echelon arrangement on the plane. Type-I faults cut the Yanchang Formation and the bottom coal and mudstone strata of the Yan'an Formation on the section and have the fault displacement greater than $40 \mathrm{~m}$ (Figures 3, 4). Their extension length is generally greater than $4.0 \mathrm{~km}$ on the plane and their directions are mainly NW-SE strikes. Type-II faults cut the Chang 7 source rock and Chang 8 reservoirs on the section, and their fault displacement is generally less than $40 \mathrm{~m}$ (Figures 3, 4). The extension length of these

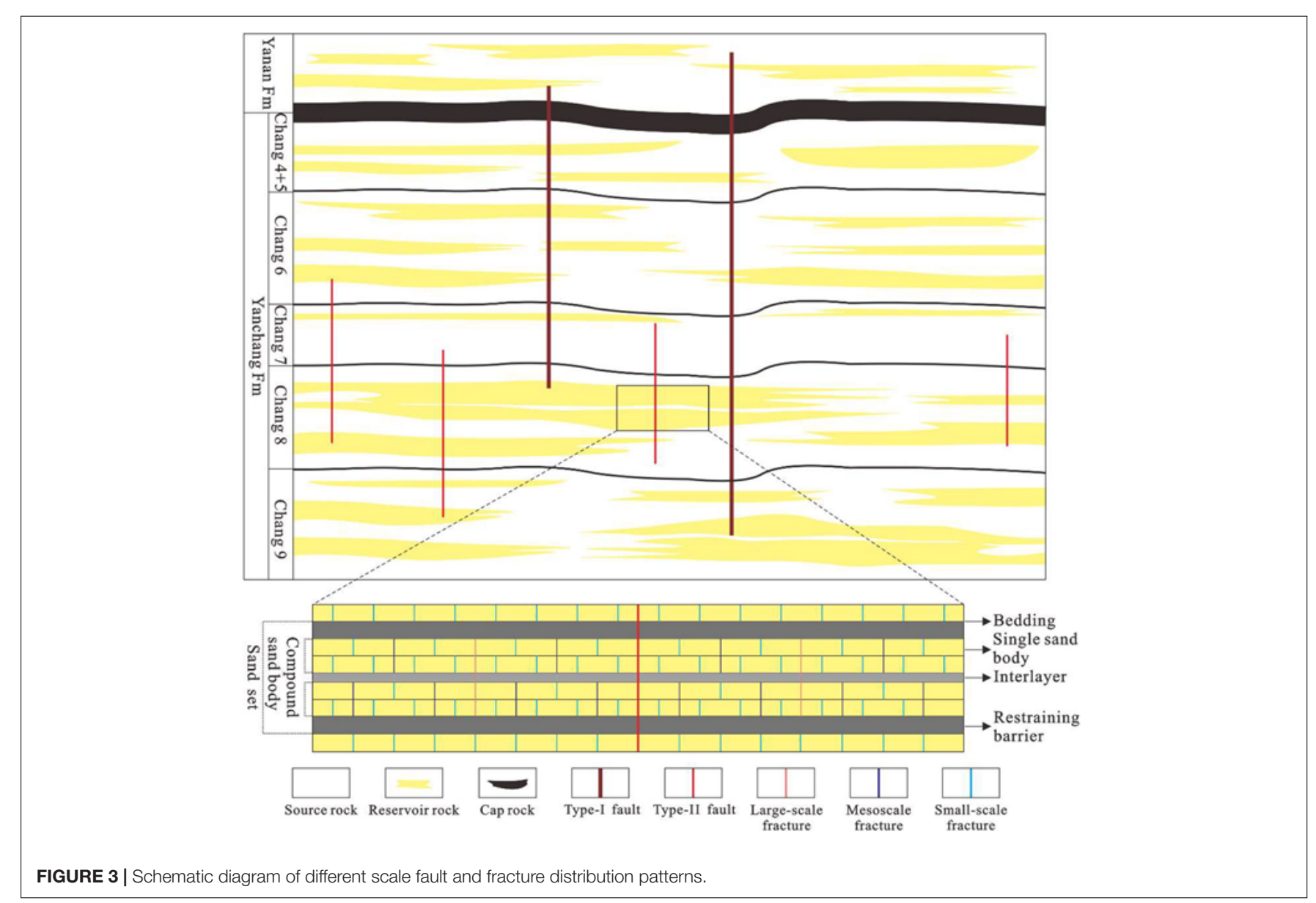


TABLE 1 | Multi-scale fault and fracture classification and their characteristics.

\begin{tabular}{|c|c|c|c|}
\hline Classification & Development characteristics & Scale & Function \\
\hline Type-I faults & $\begin{array}{l}\text { Cutting through the bottom coal seam and mud-shale } \\
\text { of Jurassic Yan'an Formation }\end{array}$ & $\begin{array}{l}\text { With the plane propagation over } 4.0 \mathrm{~km} \text {; fault displacement } \\
\text { over } 40 \mathrm{~m}\end{array}$ & Against for oil storage \\
\hline Type-II faults & $\begin{array}{l}\text { Cutting through the Chang } 7 \text { mudstones and Chang } 8 \\
\text { reservoir of the Upper Triassic Yanchang Formation }\end{array}$ & $\begin{array}{l}\text { With propagation less than } 4.0 \mathrm{~km} \text {; fault displacement less } \\
\text { than } 40 \mathrm{~m}\end{array}$ & $\begin{array}{l}\text { The fault of oil source, } \\
\text { oil migration channel }\end{array}$ \\
\hline Large-scale fractures & $\begin{array}{l}\text { Developed within the Chang } 8 \text { of the Upper Triassic } \\
\text { Yanchang Formation, cutting through interlayers of } \\
\text { sandstones and mudstones and restricted by the } \\
\text { Chang } 7 \text { mudstones of the Yanchang Formation }\end{array}$ & $\begin{array}{l}\text { With propagation ranging from hundreds of meters to } \\
\text { thousands of meters, the height is over tens of meters }\end{array}$ & Seepage channels \\
\hline Mesoscale fractures & $\begin{array}{l}\text { Developed within composite sandstone layers, cutting } \\
\text { through thin interlayers and restricted by interlayers of } \\
\text { mudstone }\end{array}$ & $\begin{array}{l}\text { With propagation ranging from tens to hundreds of meters; } \\
\text { height ranging from meters to tens of meters }\end{array}$ & Seepage channels \\
\hline Small-scale fractures & $\begin{array}{l}\text { Developed within a single sandstone layer and } \\
\text { controlled by thin interlayers or layer interfaces }\end{array}$ & $\begin{array}{l}\text { With propagation ranging from several meters to tens of } \\
\text { meters; the height of several decimeters }\end{array}$ & $\begin{array}{l}\text { Storage spaces and } \\
\text { seepage channels }\end{array}$ \\
\hline Micro-scale fractures & Developed within a single sandstone layer & $\begin{array}{l}\text { With the propagation of less than several centimeters, and } \\
\text { aperture less than } 50 \mu \mathrm{m}\end{array}$ & Storage space \\
\hline
\end{tabular}

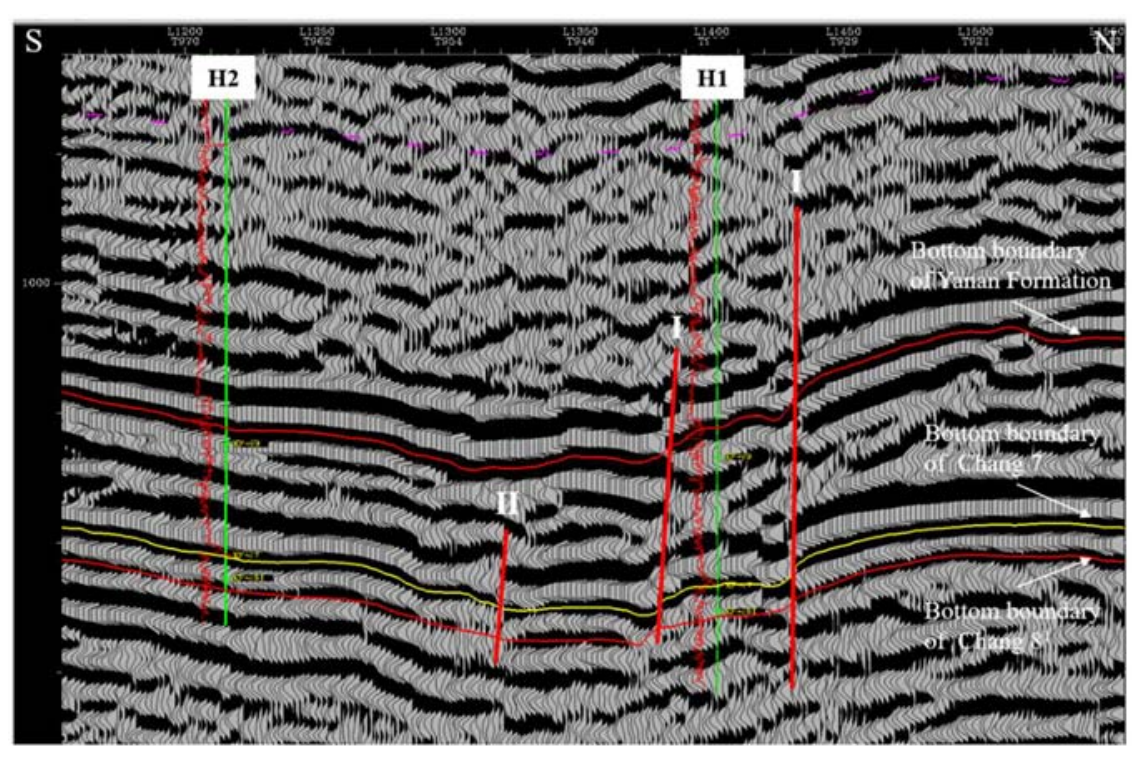

FIGURE 4 | Type-I and type-II faults on the seismic cross-section. I refers to the type-I fault. II refers to the type-II fault. H1 and H2 refer to drilling wells, see Figure $\mathbf{1}$ for the well location.

faults on the plane is less than $4.0 \mathrm{~km}$, and their directions are NEE-SWW and NWW-SEE strikes. The statistical results of seismic data interpretation show that the number of type-I faults is significantly less than that of type-II faults, reflecting that the number of faults decreases as the fault scale increases. Generally, the larger the fault scale, the greater the energy, and the more secondary faults will be formed.

Large-scale fractures are mainly identified by outcrops and the post-stack attributes such as coherence, curvature, and variance from 3D seismic data, and some large-scale fractures can be observed on the core (Figure 5a). These fractures are developed in the Chang 8 reservoirs, cutting the mudstone interlayer on the section, and were restricted by the Chang 7 mudstone (Zeng et al., 2020). The extension length of this kind of fracture ranges from several hundred meters to thousands of meters, and they are arranged in an echelon on the plane. Their height is tens of meters, and their directions are NEE-SWW and NWW-SEE strikes. Outcrops, cores, and imaging logs show that mesoscale fractures are developed in the composite sandstone layers and terminated in the thick mudstone interlayers, which can cut through thin interlayers and has a height of several meters to tens of meters on the section (Figures $5 \mathbf{b}, \mathbf{6}$ ). Outcrops and imaging logs indicate that the main directions of these fractures are NEE-SWW and NWW-SEE (Figure 7). Smallscale fractures are developed in a single sandstone layer and are controlled by thin interlayers or layer interfaces. These fractures intersect with the layer interface nearly perpendicularly, with a height of tens of centimeters, extending from several meters to tens of meters on the plane (Figure 5c). Micro-scale fractures are observed in the casting thin sections (Figure 5d). Their length is generally less than one centimeter, and their aperture is less than $50 \mu \mathrm{m}$, concentrated in $10-20 \mu \mathrm{m}$. The 

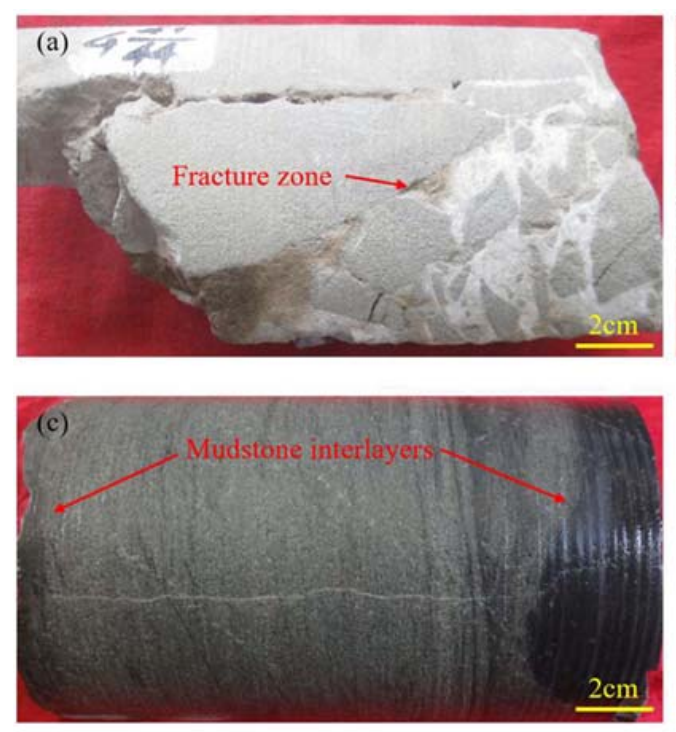
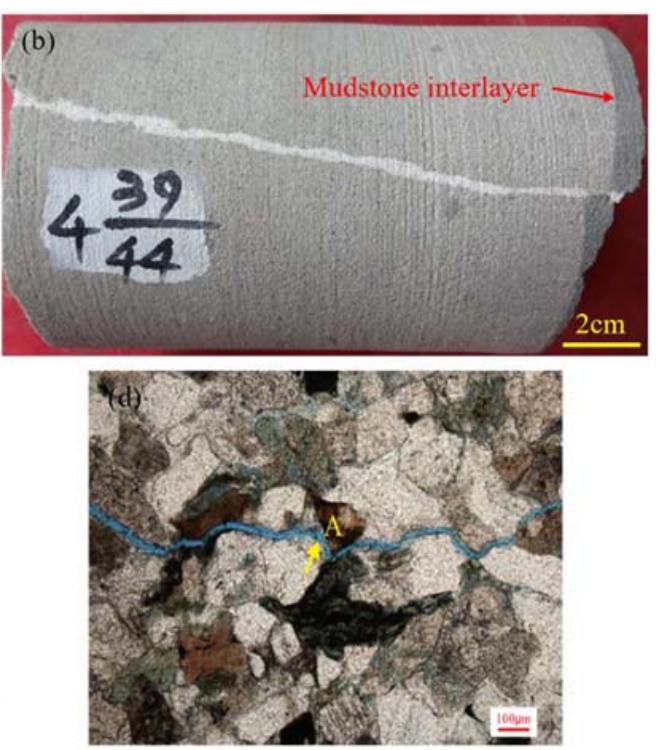

FIGURE 5 | Large-scale fracture, mesoscale fracture, small-scale fracture, and micro-scale fracture in cores and thin sections. (a) Large-scale fracture shows fracture zone, Well N2, depth of 2,309.90 m. (b) Mesoscale fracture cuts mudstone interlayer, Well N2, depth of 2,303.27 m (from Lyu et al., 2016). (c) Small-scale fracture is restricted by mudstone interlayer, Well H4, depth of 2,091.76 m, (d) Micro-scale fracture, Well H3, depth of 2,268.90 m. "A" refers to the micro-scale fracture.

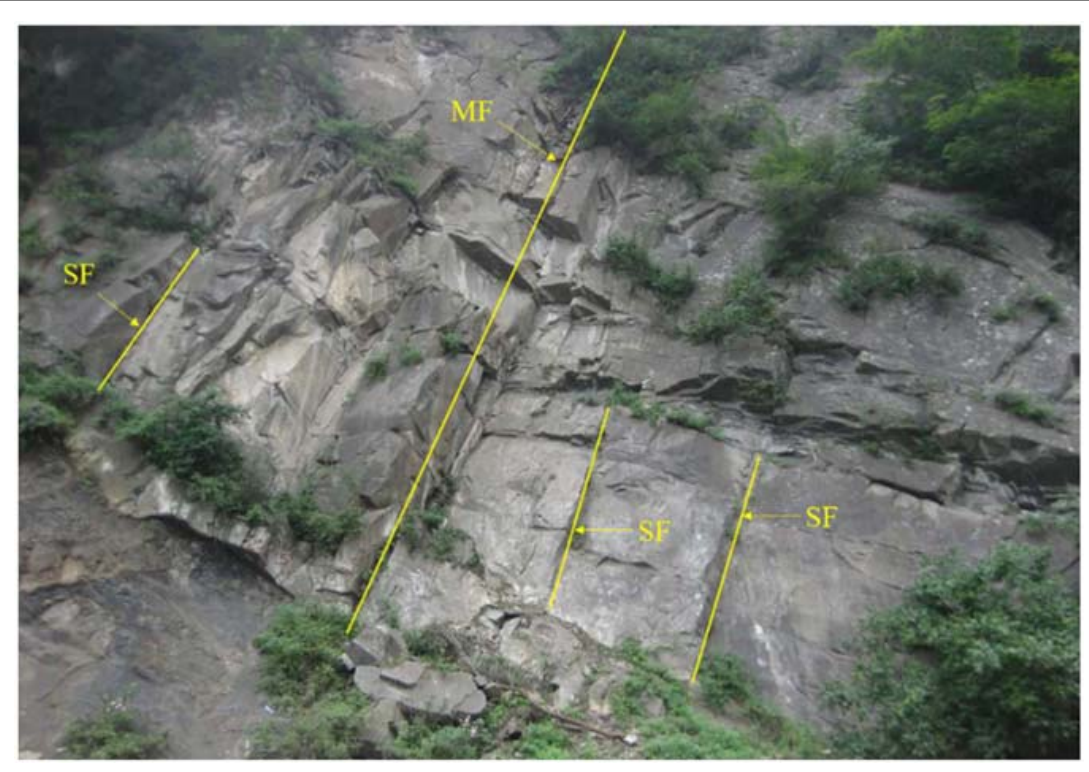

FIGURE 6 | Mesoscale and small-scale fractures in outcrops. MF refers to the mesoscale fracture; SF refers to the small-scale fracture.

statistical results show that as the fracture size increases, the density of fracture decreases, and the density of micro-scale fractures is the largest.

\section{Relationship Between Faults and Fractures}

Outcrops, cores, and imaging logs show that the development intensity of fractures is closely related to faults. As the distance from the fault plane increases, the fracture density gradually decreases (Figure 8). There is a fracture development zone near the fault plane, namely the fault damage zone (Torabi and Berg, 2011). The width of the fault damage zone is related to the scale of the fault. As the scale of the fault increases, the width of the fault damage zone becomes larger (Lyu et al., 2017b). In addition, due to the control of faults on fracture development, the degree of fracture development at different fault positions also varies. Generally, the fractures in the hanging wall are more developed 


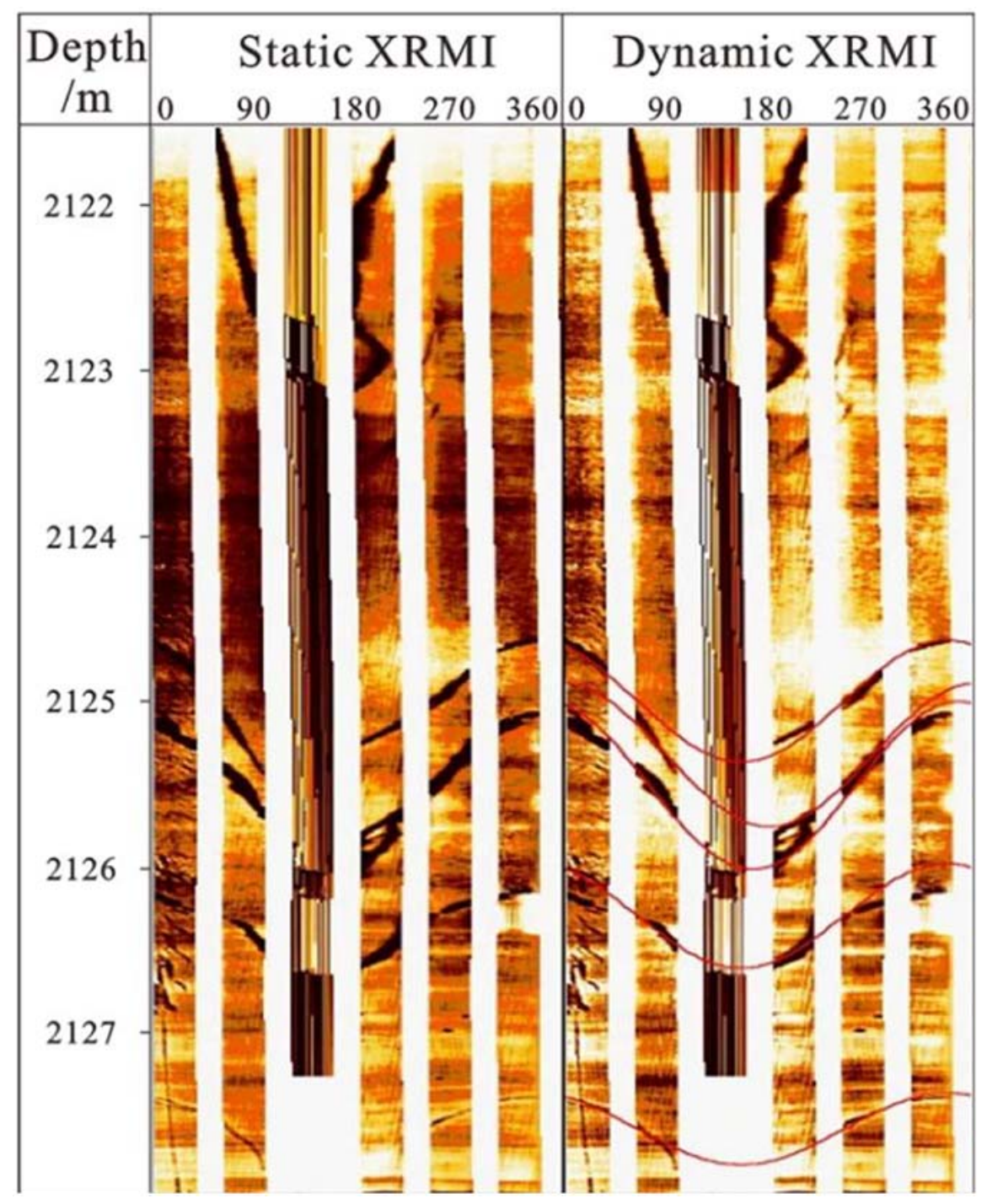

FIGURE 7 | Fractures detected by micro-resistivity imaging log in the Well H5. See Figure $\mathbf{1}$ for the location of Well H5.

than those in the footwall (Zeng, 2008). The fractures at the end of the fault are more developed than in the middle part, and the fractures at the intersection of faults and the overlapping part of echelon faults are more developed.

\section{DISCUSSION}

\section{Influence of Different Scale Faults on Oil Enrichment and Production}

The source rock of the Upper Triassic Yanchang Formation in the Ordos Basin is the Chang 7 mudstone. The reservoir is the Chang 8 sandstones. The regional caprock is the Yan 10 coalmeasure strata at the bottom of the Yan'an Formation. Type-I faults cut reservoirs, source rocks, and regional caprocks, and easily cause the loss of oil and gas. The analysis of geochemical data shows that the geochemical characteristics of the crude oils of the Mesozoic oil layer groups in the Honghe Oilfield are similar (Ma et al., 2015), reflecting that they come from the same oil source. The oil in the tight reservoirs at the bottom of the Yan'an Formation are a hydrocarbon generated from the Chang 7 source rocks of the Yanchang Formation (Xing et al., 2016), which is powerful evidence that the type-I faults zone are not conducive to the oil and gas preservation of the Chang 8 sandstone reservoir. Moreover, although the fluid production of the wells drilled through type-I faults is high, the oil production of these wells is low, mainly water production (Figure 9). Therefore, type-I faults contribute the most to the fluid flow in the reservoirs but are not conducive to the enrichment and production of tight oil in the Chang 8.

Type-II faults connect the Chang 7 source rocks and the Chang 8 reservoirs in the study area and are oil source faults and the main migration channels for oil. In addition, due to the more developed fractures near the fault, tight oil production 


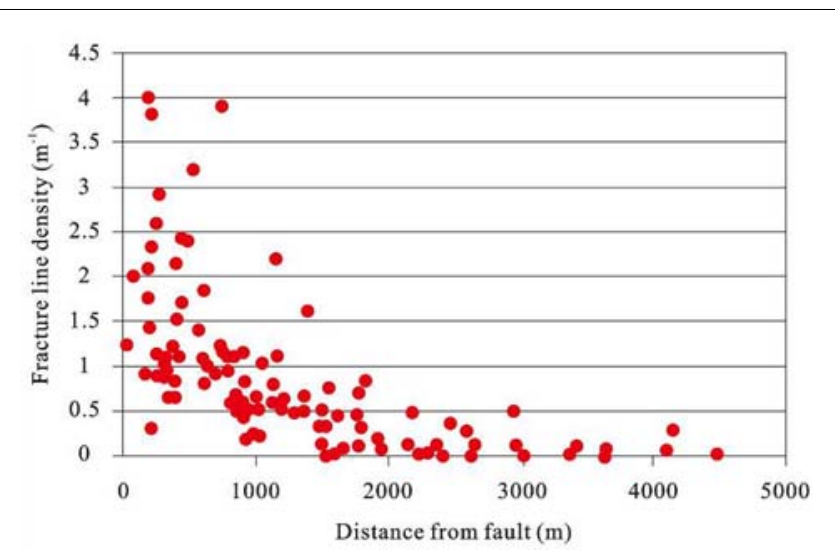

FIGURE 8 | The relationship between fracture density and distance from the fault.

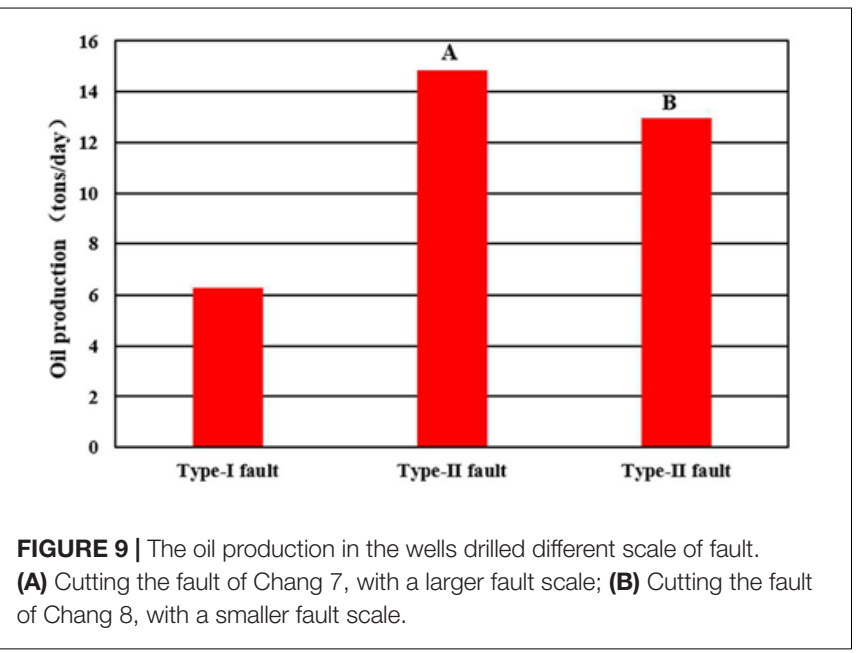

is generally high when drilling through the type-II faults zone. According to the oil test data in the reservoirs, although the fluid output of wells drilling through the type-II faults zone is not as high as that drilling through that of type-I faults, the oil production of wells drilling through the type-II faults zone is significantly higher than that drilling through that of type-I faults. The average oil production of wells drilled through the type-II faults zone with an extension length of 1,000-4,000 m exceeds 12 tons per day, while the average oil production of wells drilled through that of type-I faults is less than six tons per day (Figure 10).

There are apparent differences in the impact of faults with different directions on oil production. There are two sets of nearly upright faults in the NWW-SEE and NEE-SWW directions in the tight sandstones of the Upper Triassic Yanchang Formation in the southwestern Ordos Basin. According to the statistics of oil test data, the average oil production of wells drilled into the NWW-SEE fault is greater than 10 tons per day, while the average oil production of the wells drilled into the NEE-SWW fault is less than six tons per day (Figure 11). It indicates that the oil production of wells with NWW-SEE faults that are nearly parallel to the present maximum principal stress direction is higher than that of wells with NWW-SEE faults. This is because under the influence of the present in situ stress in the NEE-SWW direction, the NEE-SWW fault is in a state of tension currently, and the faults and their related fractures have larger apertures, better effectiveness and connectivity, and higher permeability (Liu et al., 2020b). On the contrary, the NWW-SEE fault is in a compressed state currently, and these faults and their related fractures have smaller apertures, poorer effectiveness and connectivity, and lower permeability. Therefore, the multi-scale faults and fractures that are nearly parallel to the present maximum principal stress direction significantly contribute to the oil productivity of tight sandstone reservoirs.

In different positions of the fault, the development degree of fractures is diverse, and oil production also varies greatly. Based on the statistical results of the oil test data, the oil production of wells on the fault hanging wall is higher than that of wells on the fault footwall (Figure 12). In the same fault, the wells' oil production at the end part of the fault is higher than that of the wells in the middle part of the fault. Additionally, the oil production is highest at the intersection of faults (cross part)

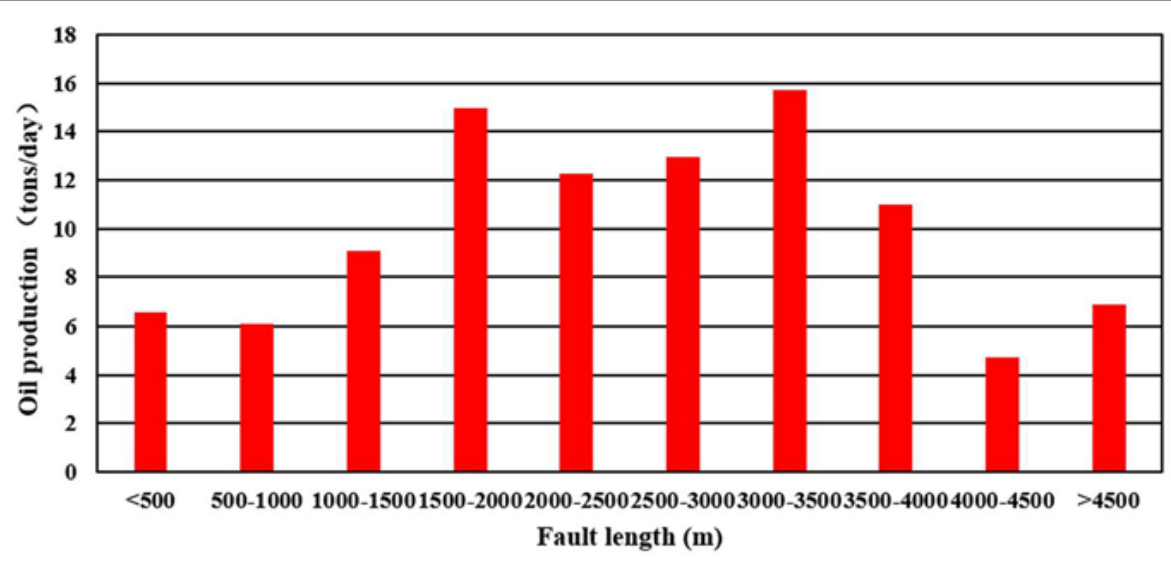

FIGURE 10 | The oil production in the wells drilled different length of fault. 


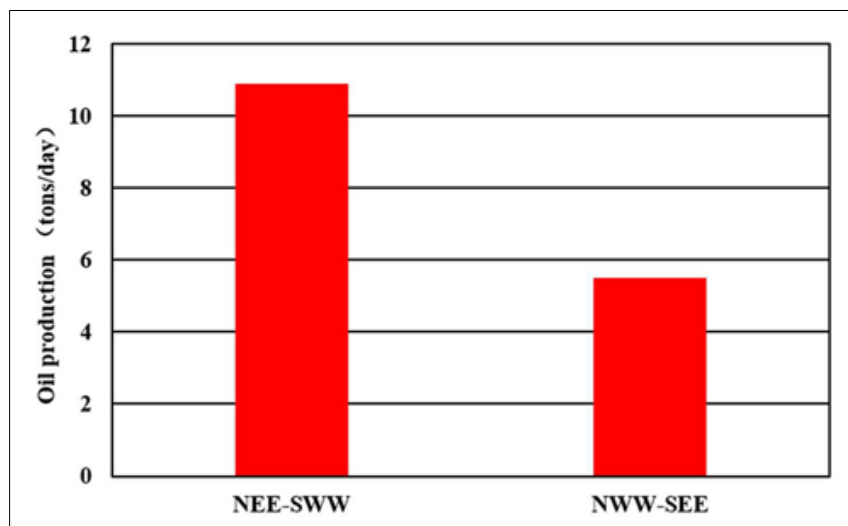

FIGURE 11 | The oil production in the wells drilled different strike of fault.

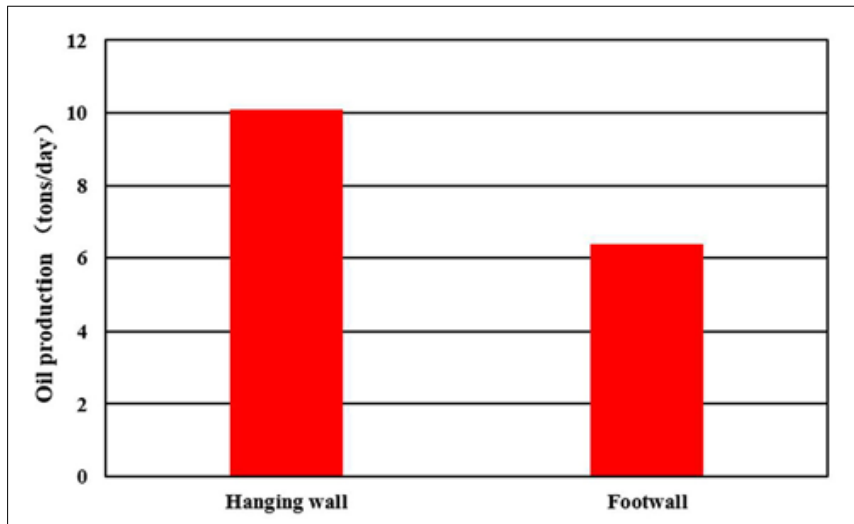

FIGURE 12 | The oil production in the wells located at hanging wall and foot wall of fault.

with different strikes and the overlaps of faults (cross part) with the same strike in an echelon arrangement (Figure 13). This proves that the difference in fracture development at different fault positions controls the difference in oil enrichment of tight sandstones and the production of single wells.

\section{Influence of Different Scale Fractures on Oil Production}

Different scale fractures are developed and distributed variedly in the tight sandstone reservoirs, which are effective storage spaces and main seepage channels and have variously effects on oil production. The tight oil in the Chang 8 reservoir is generated from the overlying Chang 7 source rocks. Due to the existence of near-upright type-II faults and large-scale fractures, tight oil preferentially charged and accumulated into reservoirs locally, showing the characteristics of "near-source vertical short distance" enrichment (Guo, 2017). The distribution of mesoscale fractures is controlled by thick interlayers, and small-scale fractures are controlled by thin interlayers or layer interfaces. Besides, the fluid flow in the tight-oil sandstones may have been largely controlled by intraformational natural fractures, which provide major fluid-flow channels. Therefore, meso- and smallscale fractures still control the internal flow of fluid in Chang 8

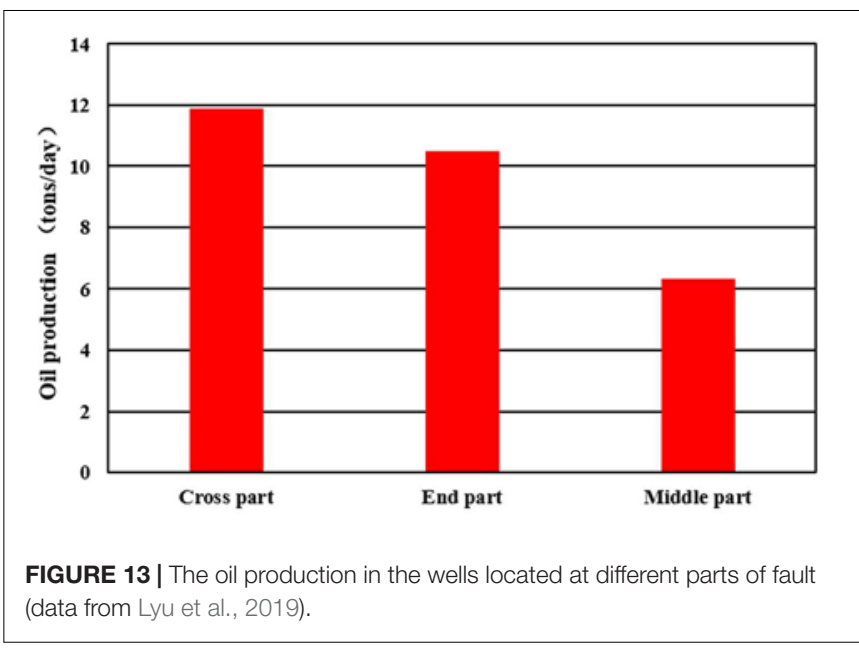

reservoir. Meso- and small-scale fractures include near vertical, high, medium, low, and nearly horizontal dip angles (Lyu et al., 2016). Meso- and small-scale fractures with various dip angles are intertwined to form a fracture network system with good connectivity and permeability. This system significantly improves the seepage capacity and effectiveness of storage space in tight sandstone reservoirs, showing that the cumulative oil production of the wells drilled fracture zone is much greater than that of wells not drilled into fracture zones. There is a positive correlation between the density of meso- and small-scale fractures and initial production $\left(R^{2}=0.838\right)$ (Lyu et al., 2019). As the density of meso- and small-scale fractures increases, the initial production of wells increases. Besides, away from the fault damage zones, the initial oil production decreases. This decrease law could also be ascribed to the decreasing fracture intensity away from faults. The exploration and development status mentioned above reflects that meso- and small-scale fractures are the key factors to control the oil production of tight sandstone reservoirs.

The porosity and permeability of fractures can characterize the migration and storage capacity of fluids (Gong et al., 2021). According to the calculation results of porosity and permeability, small-scale fractures can increase the permeability of tight sandstone reservoirs by 1-2 orders of magnitude, and their porosity is similar to the reservoir matrix (Lyu et al., 2019). This means that the small-scale fractures mainly improve the reservoir permeability and secondly serve as the reservoir storage space. The micro-scale fractures are distributed in the tight sandstones with the largest number, and their fracture porosity is also the largest. Micro-scale fractures can be regarded as relatively large-scale pores, it is used as a storage space first, and then as a migration channel. As the distance from the fault plane decreases, the density of micro-scale fractures increases. Type-II faults migrate oil and gas to the Chang 8 reservoir, and preferentially enrich and accumulate in the micro-fractures near the faults. Or oil and gas migrate from large-scale, mesoscale, and small-scale fractures, and enrich in micro-scale fractures near these fractures. The above reasons enable the micro-scale fractures to have considerable oil storage 
capacity, which is an important factor influencing the stable production of tight sandstone reservoirs. Besides, micro-scale fractures nucleate at stress concentrations that occur at the grain scale. Once micro-scale fractures become longer than that length scale, i.e., become transgranular, they may continue to propagate by virtue of the stress concentration at the tip and become macrofractures (Anders et al., 2014). From this perspective, some fractures may grow into cracks microscale larger scale potential as migration pathways of hydrocarbon and have considerable capacity enrichment. A parallelism between the orientation of micro-scale fractures and larger micro-scale fractures (Laubach and Diaz-Tushman, 2009), we can take advantage of the distribution law and development characteristics of larger-scale fractures to determine well pattern deployment and fracturing plans to further achieve high and stable production of tight oil.

\section{CONCLUSION}

The faults and fractures of the tight oil sandstone reservoirs of the Upper Triassic Yanchang Formation in the southwestern Ordos Basin are divided into six levels: type-I faults, typeII faults, large-scale fractures, mesoscale fractures, small-scale fractures, and micro-scale fractures. Type-I faults cut through the regional caprocks and cause the loss of oil. Type-II faults connect the source rocks and the reservoirs and act as oil migration channels. Large-scale fractures are developed in the reservoirs, cut the mudstone interlayer, and are the seepage channel inside the reservoir. Mesoscale fractures are developed in the composite sandstone layers and are controlled by thick mudstone interlayers. Small-scale fractures are developed in a single sandstone layer and are restricted by thin interlayers or layer interfaces. Meso- and small-scale fractures are the main seepage channels and effective storage spaces for tight reservoirs. The micro-scale fractures are observed in the casting thin sections and are important storage space for tight oil sandstone reservoirs.

The scale, strike, and position of the fault will change the development degree of fractures, leading to different oil production in a single well of tight sandstone reservoirs. TypeI faults contribute the most to regional fluid flow but are not conducive to the enrichment and high oil production in the Chang 8 tight sandstone reservoirs. Fractures near type-II faults are more developed, which is favorable to oil enrichment and generally has higher oil production. The faults and fractures that are nearly parallel to the present maximum principal stress

\section{REFERENCES}

Ameen, M. S., and Hailwood, E. A. (2008). A new technology for the characterization of microfractured reservoirs (test case: Unayzah reservoir, Wudayhi field, Saudi Arabia). Am. Assoc. Pet. Geol. Bull. 92, 31-52. doi: 10. 1306/08200706090

Ameen, M. S., MacPherson, K., Al-Marhoon, M. I., and Rahim, Z. (2012). Diverse fracture properties and their impact on performance in conventional and tightgas reservoirs, Saudi Arabia: The Unayzah, South Haradh case study. Am. Assoc. Pet. Geol. Bull. 96, 459-492. doi: 10.1306/06011110148 direction greatly contribute to the oil productivity of tight sandstones. In the intersections and overlaps (cross parts), and end parts of faults, fractures are more developed, and single well oil production is higher. The development degree of meso- and small-scale fractures is the key to influencing the early singlewell production in tight sandstone reservoirs. The more mesoand small-scale fractures are developed, the higher the singlewell production is. The development of micro-scale fractures is conducive to the stable production of single wells in tight sandstone reservoirs.

Multi-scale faults and fractures have significantly different effects on the oil enrichment and production of tight sandstone reservoirs. Consequently, it is necessary to pay more attention to their development and distribution law to better refer to the exploration and development of tight oil sandstone reservoirs.

\section{DATA AVAILABILITY STATEMENT}

The original contributions presented in the study are included in the article/Supplementary Material, further inquiries can be directed to the corresponding author/s.

\section{AUTHOR CONTRIBUTIONS}

LZ and WL contributed to conception and design of the study, organized the database, and performed the statistical analysis. LZ, WL, YZ, and GL wrote the first draft of the manuscript. SD wrote sections of the manuscript. All authors contributed to manuscript revision, read, and approved the submitted version.

\section{FUNDING}

This study was financially supported by the National Natural Science Foundation of China (Grant No. 42002135) and the Science Foundation of China University of Petroleum, Beijing (2462017YJRC057).

\section{ACKNOWLEDGMENTS}

We are particularly grateful to Frontiers in Earth Science editor and reviewers for their thorough and constructive comments, which will improve the manuscript significantly.

Anders, M. H., Laubach, S. E., and Scholz, C. H. (2014). Microfractures: a review. J. Struct. Geol. 69, 377-394. doi: 10.1016/j.jsg.2014.05.011

Barton, C., Moos, D., and Tezuka, K. (2009). Geomechanical wellbore imaging: implications for reservoir fracture permeability. Am. Assoc. Pet. Geol. Bull. 93, 1551-1569. doi: 10.1306/06180909030

Berkowitz, B. (2002). Characterizing flow and transport in fractured geological media: a review. Adv. Water Resour. 25, 861-884. doi: 10.1016/S0309-1708(02) 00042-8

Chen, S. Q., Zeng, L. B., Huang, P., Sun, S. H., Zhang, W. L., and Li, X. Y. (2016). The application study on the multi-scales integrated prediction method to 
fractured reservoir description. Appl. Geophys. 13, 80-92. doi: 10.1007/s11770016-0531-7

Cooke, M. L., Simo, J. A., Underwood, C. A., and Rijken, P. (2006). Mechanical stratigraphic controls on fracture patterns within carbonates and implications for groundwater flow. Sediment. Geol. 184, 225-239. doi: 10.1016/j.sedgeo.2005. 11.004

Duan, Y., Wang, C. Y., Zheng, C. Y., Wu, B. X., and Zheng, G. D. (2008). Geochemical study of crude oils from the Xifeng oilfield of the Ordos basin, China. J. Asian Earth Sci. 31, 341-356. doi: 10.1016/j.jseaes.2007.05.003

Gong, L., Fu, X., Wang, Z., Gao, S., Jabbari, H., Yue, W., et al. (2019). A new approach for characterization and prediction of natural fracture occurrence in tight oil sandstones with intense anisotropy. Am. Assoc. Pet. Geol. Bull. 103, 1383-1400. doi: 10.1306/12131818054

Gong, L., Wang, J., Gao, S., Fu, X., Liu, B., Miao, F., et al. (2021). Characterization, controlling factors and evolution of fracture effectiveness in shale oil reservoirs. J. Pet. Sci. Eng. 203:108655. doi: 10.1016/j.petrol.2021.108655

Gross, M. R., Fischer, M. P., Engelder, T., and Greenfield, R. J. (1995). Factors controlling joint spacing in interbedded sedimentary rocks: integrating numerical models with field observations from the Monterey Formation, USA. Geol. Soc. Spec. Publ. 92, 215-233. doi: 10.1144/GSL.SP.1995.092.01.12

Guo, K. (2017). Active source rocks of Chang 7 member and hydrocarbon generation and expulsion characteristics in Longdong area, Ordos Basin. Pet. Geol. Exp 39, 15-23.

Han, S., Horsfield, B., Zhang, J., Chen, Q., Mahlstedt, N., Di Primio, R., et al. (2014). Hydrocarbon generation kinetics of lacustrine Yanchang shale in Southeast Ordos Basin. North China. Energy Fuels 28, 5632-5639. doi: 10.1021/ef501011b

Han, Y., Horsfield, B., Wirth, R., Mahlstedt, N., and Bernard, S. (2017). Oil retention and porosity evolution in organic-rich shales. Am. Assoc. Pet. Geol. Bull. 101, 807-827. doi: 10.1306/09221616069

Hao, L., Tang, J., Wang, Q., Tao, H., Ma, X., Ma, D., et al. (2017). Fractal characteristics of tight sandstone reservoirs: a case from the Upper Triassic Yanchang Formation, Ordos Basin, China. J. Pet. Sci. Eng. 158, 243-252. doi: 10.1016/j.petrol.2017.08.060

Hennings, P. H., Olson, J. E., and Thompson, L. B. (2000). Combining outcrop data and three-dimensional structural models to characterize fractured reservoirs: an example from Wyoming. Am. Assoc. Pet. Geol. Bull. 84, 830-849. doi: 10.1306/ a967340a-1738-11d7-8645000102c1865d

Hillis, R. R., and Reynolds, S. D. (2003). In situ stress field of Australia. Spec. Pap. Geol. Soc. Am. 372, 49-58. doi: 10.1130/0-8137-2372-8.49

Jia, C. (2017). Breakthrough and significance of unconventional oil and gas to classical petroleum geological theory. Pet. Explor. Dev. 44, 1-11. doi: 10.11698/ PED.2017.01.01

Ju, W., Shen, J., Qin, Y., Meng, S., Wu, C., Shen, Y., et al. (2017). In-situ stress state in the Linxing region, eastern Ordos Basin, China: implications for unconventional gas exploration and production. Mar. Pet. Geol. 86, 66-78. doi: 10.1016/j.marpetgeo.2017.05.026

Khoshbakht, F., Azizzadeh, M., Memarian, H., Nourozi, G. H., and Moallemi, S. A. (2012). Comparison of electrical image log with core in a fractured carbonate reservoir. J. Pet. Sci. Eng. 8, 289-296. doi: 10.1016/j.petrol.2012.03.007

Larsen, B., Gudmundsson, A., Grunnaleite, I., Sælen, G., Talbot, M. R., and Buckley, S. J. (2010). Effects of sedimentary interfaces on fracture pattern, linkage, and cluster formation in peritidal carbonate rocks. Mar. Pet. Geol. 27, 1531-1550. doi: 10.1016/j.marpetgeo.2010.03.011

Laubach, S. E., and Diaz-Tushman, K. (2009). Laurentian palaeostress trajectories and ephemeral fracture permeability, Cambrian Eriboll Formation sandstones west of the Moine Thrust Zone, NW Scotland. J. Geol. Soc. London. 166, 349-362. doi: 10.1144/0016-76492008-061

Laubach, S. E., Eichhubl, P., Hilgers, C., and Lander, R. H. (2010). Structural diagenesis. J. Struct. Geol. 32, 1866-1872. doi: 10.1016/j.jsg.2010.10.001

Laubach, S. E., and Ward, M. E. (2006). Diagenesis in porosity evolution of opening-mode fractures, Middle Triassic to Lower Jurassic La Boca Formation, NE Mexico. Tectonophysics 419, 75-97. doi: 10.1016/j.tecto.2006.03.020

Liang, C., and Guo, J. (2017). Diagenesis and reservoir characteristics of tight sandstones of Chang 8_1 member of Yanchang Formation in Honghe oilfield,Ordos Basin. Pet. Geol. Recover. Effic 24, 57-63.

Liu, G. P., Zeng, L. B., Han, C. Y., Mehdi, O., Lyu, W. Y., Wang, Q. Q., et al. (2020a). Natural Fractures in Carbonate Basement Reservoirs of the Jizhong Sub-Basin,
Bohai Bay Basin, China: key Aspects Favoring Oil Production. Energies 13:4635. doi: 10.3390/en13184635

Liu, G. P., Zeng, L. B., Sun, G., Zu, K., Qin, L., Mao, Z., et al. (2020b). Natural fractures in tight gas volcanic reservoirs and their influences on production in the Xujiaweizi Depression, Songliao Basin, China. Am. Assoc. Pet. Geol. Bull. 104, 2099-2123. doi: 10.1306/05122017169

Lyu, W., Zeng, L., Liu, Z., Liu, G., and Zu, K. (2016). Fracture responses of conventional logs in tight-oil sandstones: a case study of the Upper Triassic Yanchang Formation in southwest Ordos Basin, China. Am. Assoc. Pet. Geol. Bull. 100, 1399-1417. doi: 10.1306/04041615129

Lyu, W., Zeng, L., Liao, Z., Ji, Y., Lyu, P., Dong, S., et al. (2017a). Fault damage zone characterization in tight-oil sandstones of the Upper Triassic Yanchang formation in southwest Ordos Basin, China: Integrating cores, image logs and conventional logs. Interpretation 5. doi: 10.1190/int-2016-0231.1

Lyu, W., Zeng, L., Zhang, B., Miao, F., Lyu, P., and Dong, S. (2017b). Influence of natural fractures on gas accumulation in the Upper Triassic tight gas sandstones in the northwestern Sichuan Basin, China. Mar. Pet. Geol. 83, 60-72. doi: 10.1016/j.marpetgeo.2017.03.004

Lyu, W., Zeng, L., Zhou, S., Du, X., Xia, D., Liu, G., et al. (2019). Natural fractures in tight-oil sandstones: a case study of the upper triassic yanchang formation in the southwestern ordos basin, China. Am. Assoc. Pet. Geol. Bull. 103, 2343-2367. doi: 10.1306/0130191608617115

Ma, L., Yin, H., Chen, C., and Yin, W. (2015). Research of geochemistry characteristics and source of crude oils from the Honghe Oilfield in the Ordos Basin. Acta Sedimentol. Sin. 33, 416-425.

Olson, J. E. (2003). Sublinear scaling of fracture aperture versus length: an exception or the rule? J. Geophys. Res: Solid Earth. 108:B9. doi: 10.1029/ 2001jb000419

Rajabi, M., Tingay, M., and Heidbach, O. (2016). The present-day state of tectonic stress in the Darling Basin, Australia: implications for exploration and production. Mar. Pet. Geol. 77, 776-790. doi: 10.1016/j.marpetgeo.2016.07.021

Shi, J., Zeng, L., Zhao, X., Zhang, Y., and Wang, J. (2020). Characteristics of natural fractures in the upper Paleozoic coal bearing strata in the southern Qinshui Basin, China: implications for coalbed methane (CBM) development. Mar. Pet. Geol. 113:104152. doi: 10.1016/j.marpetgeo.2019.104152

Strijker, G., Bertotti, G., and Luthi, S. M. (2012). Multi-scale fracture network analysis from an outcrop analogue: a case study from the Cambro-Ordovician clastic succession in Petra, Jordan. Mar. Pet. Geol. 38, 104-116. doi: 10.1016/j. marpetgeo.2012.07.003

Tang, X., Zhang, J., Wang, X., Yu, B., Ding, W., Xiong, J., et al. (2014). Shale characteristics in the southeastern Ordos Basin, China: implications for hydrocarbon accumulation conditions and the potential of continental shales. Int. J. Coal Geol. 12, 32-46. doi: 10.1016/j.coal.2014.03.005

Torabi, A., and Berg, S. S. (2011). Scaling of fault attributes: a review. Mar. Pet. Geol. 28, 1444-1460. doi: 10.1016/j.marpetgeo.2011.04.003

Wang, Y., Chang, X., Sun, Y., Shi, B., and Qin, S. (2020). Investigation of fluid inclusion and oil geochemistry to delineate the charging history of Upper Triassic Chang 6, Chang 8, and Chang 9 tight oil reservoirs, Southeastern Ordos Basin, China. Mar. Pet. Geol 113:104115. doi: 10.1016/j.marpetgeo.2019.10 4115

Wang, Y., Liu, L., Li, S., Ji, H., Xu, Z., Luo, Z., et al. (2017). The forming mechanism and process of tight oil sand reservoirs: a case study of Chang 8 oil layers of the Upper Triassic Yanchang Formation in the western Jiyuan area of the Ordos Basin, China. J. Pet. Sci. Eng. 158, 29-46. doi: 10.1016/j.petrol.2017.08.026

Xing, L., Xu, L., Zhao, Y., Wang, X., and Zhou, D. (2016). Hydrocarbon Accumulation of Linzhen Yanan Formation in Ordos Basin. Spec. Oil Gas Reserv 23, 14-18.

Xu, S., Hao, F., Gou, Q., Liu, R., Liu, J., and Tian, J. (2020). Multiscale Faults and Fractures Characterization and Their Effects on Shale Gas Accumulation in the Jiaoshiba Area, Sichuan Basin, China. J. Pet. Sci. Eng 189:107026. doi: 10.1130/abs/2019am-338586

Zeng, L. (2008). Formation and Distribution of Fractures in Low-permeability Sandstone Reservoirs. Beijing: Science Press.

Zeng, L., and Li, X. (2009). Fractures in sandstone reservoirs with ultra-low permeability: a case study of the Upper Triassic Yanchang Formation in the Ordos Basin, China. Am. Assoc. Pet. Geol. Bull. 93, 461-477. doi: 10.1306/ 09240808047 
Zeng, L., Li, Z., Shi, C., Wang, Z., Zhao, J., and Wang, Y. (2007). Characteristics and origin of fractures in the extra low-permeability sandstone reservoirs of the Upper Triassic Yanchang Formation in the Ordos Basin. Acta Geol. Sin. 81, 174-180.

Zeng, L., Lyu, P., Qu, X., and Fan, J. (2020). Multi-scale fractures in tight sandstone reservoirs with low permeability and geological conditions of their development. Oil Gas Geol. 41, 449-454. doi: 10.11743/ogg20200301

Zeng, L., Su, H., Tang, X., Peng, Y., and Gong, L. (2013). Fractured tight sandstone oil and gas reservoirs: a new play type in the Dongpu depression, Bohai Bay Basin, China. Am. Assoc. Pet. Geol. Bull. 97, 363-377. doi: 10.1306/0912121 2057

Zeng, L. B., Gao, C. Y., Qi, J. F., Wang, Y. K., Li, L., and Qu, X. F. (2008). The distribution rule and seepage effect of the fractures in the ultra-low permeability sandstone reservoir in east Gansu Province, Ordos Basin. Sci. China Ser. D Earth Sci. 51, 44-52. doi: 10.1007/s11430-008-6015-8
Zoback, M. D., Barton, C. A., Brudy, M., Castillo, D. A., Finkbeiner, T., Grollimund, B. R., et al. (2003). Determination of stress orientation and magnitude in deep wells. Int. J. Rock Mech. Min. Sci. 40, 1049-1076. doi: 10.1016/j.ijrmms.2003. 07.001

Conflict of Interest: The authors declare that the research was conducted in the absence of any commercial or financial relationships that could be construed as a potential conflict of interest.

Copyright (c) 2021 Zeng, Lyu, Zhang, Liu and Dong. This is an open-access article distributed under the terms of the Creative Commons Attribution License (CC BY).

The use, distribution or reproduction in other forums is permitted, provided the original author(s) and the copyright owner(s) are credited and that the original publication in this journal is cited, in accordance with accepted academic practice. No use, distribution or reproduction is permitted which does not comply with these terms. 